\title{
Co-creating Value in Higher Education: The Role of Interactive Classroom Response Technologies
}

\author{
Dr. Jana Lay-Hwa. Bowden (Corresponding author) \\ Department of Marketing \& Management, Faculty of Business and Economics \\ Macquarie University, North Ryde 2109, Sydney, Australia \\ Tel: 61-2-9850-1813 E-mail: jana.bowden@mq.edu.au \\ Dr. Steven D’Alessandro \\ Department of Marketing \& Management, Faculty of Business and Economics \\ Macquarie University, North Ryde 2109, Sydney, Australia \\ Tel: 61-2-9850-4849 E-mail: steven.dalessandro@mq.edu.au
}

\begin{abstract}
Received: September 8, 2011
Accepted: October 11, $2011 \quad$ Published: November 1, 2011

doi:10.5539/ass.v7n11p35

URL: http://dx.doi.org/10.5539/ass.v7n11p35
\end{abstract}

The research was financed by the LEAD learning and teaching program in the Faculty of Business \& Economics, Macquarie University.

\begin{abstract}
As competition intensifies, it is essential that higher education providers endeavour to develop and offer high quality, satisfaction-creating service experiences. This requires a comprehensive understanding of the factors that lead to positive perceptions of the institutions services. Current perspectives suggest that the student should be engaged as an active co-producer of the university experience. Interactive classroom technologies may enhance the student experience by encouraging participation. This study examines whether student perceived value, namely social or functional value, satisfaction, and loyalty differs for students participating in a personal response technology enabled classroom experience, versus a more traditional classroom experience. A partial least squares approach was adopted using a sample of 184 students. The use of personal response technology was not found to be positively related to the student experience. In the current context, it appeared to break classroom social patterns resulting in an individualistic, disengaging educational experience. Interestingly, in the traditional, non-technology condition social interaction was enhanced and social value strongly determined students' perceptions of loyalty. These results suggest that it is the pedagogy, and not the technology that matters in higher education provision. Conclusions, implications and opportunities for future research are presented.
\end{abstract}

Keywords: Technology, Perceived value, Co-creation, Participation, Loyalty, Higher education

\section{Introduction}

During the last decade there has been a growing interest in understanding and managing the student experience. This interest appears to have been driven by a range of challenges that tertiary institutions are presently dealing with including high student drop-out rates, a student population that views tertiary education as a necessity rather than as a privilege, political and economic pressure to be more responsive to industry needs, as well as an increasingly globalised competitive environment (Helgesen, 2008; Mansfield \& Warwick, 2006; Yang, Allessandri \& Kinsey, 2008). These new marketing challenges have necessitated a need to more comprehensively understand the university experience from the student's perspective as well as the factors that lead to high levels of student satisfaction and loyalty (Mansfield \& Warwick, 2006). This is particularly relevant for the first year student since it is the first year where students' expectations with regard to their learning, the quality of their education as well as the value that they perceive from their qualification are established (Nicol, 2006). Understanding the determinants of positive student experiences is therefore becoming an increasingly important strategic theme for higher education institutions given that this allows institutions to achieve their 
organisational goals. The retention of students is now considered equally as important as the attraction of them (Helgesen, 2008; Hemsley-Brown \& Oplatka, 2006).

Like any other organisation, higher education providers rely upon offering high quality, satisfaction-creating service experiences to remain competitive within the sector. This includes the development of higher education services which meet and potentially exceed students' expectations, and which provide students with an enriching educational experience. A quality educational experience goes beyond simply providing a tertiary programme built based on academic rigor, and the functional delivery of informative classes; as Yeo (2009) notes, it encompasses a whole-of-person, growth oriented experience. This developmental experience is achieved inside and outside the classroom, as well as between educators and students, and between members of the student body itself. Understanding the tertiary student experience and delivering an exceptional educational service therefore requires the adoption of a student-centred framework (Thomas \& Cunningham, 2009). A marketing orientation can assist with this approach since an understanding of students' evaluation processes enables institutions to develop a high quality tertiary experience to meet students' needs (Thomas \& Cunningham, 2009; Marsfield \& Warwick, 2006; Helgesen, 2008).

In line with this marketing orientation, a recently espoused view is to conceptualise the student as a customer of the institution. This perspective sees the student and the institution as being in a dynamic and mutual process of co-production and value exchange (Vargo \& Lusch 2004). Both constituents work together to create the educational experience. Student involvement in the educational exchange is therefore central to the achievement of both pedagogical and business outcomes. Within this framework, customer value has emerged as an important concept. Understanding students' needs and subsequently providing superior value may enable tertiary institutions to deliver greater levels of satisfaction to students, tailor educational offerings to their needs and also optimize their learning experience (Ledden, Kalafatis \& Samouel, 2007). In addition the provision of superior value relative to competitors has been found to lead to higher levels of student retention, recommendation and return (LeBlanc \& Nguyen, 1999). However, to date, little is understood about; the nature of perceived value in higher education, how value is created and the mechanisms for enhancing perceived value.

Research is required to explore the role of technology and its impact upon student perceived value. This is because institutions are dealing with a highly technologically adept student base which is accustomed to using technological advancements during their educational development (Kennedy, Judd, Chruchward, Gray \& Krause, 2008). Given that technology is likely to be a major force in shaping student's interactions with and evaluations of tertiary institutions in the future, it would be beneficial to examine how technology influences the student perceived value-loyalty chain. Parasuraman and Grewal (2000) for example note that it is important to determine whether the same conceptual factors within an interpersonal service exchange remain relevant or important in a technology facilitated exchange. For example, does the use of interactive technologies in class based instruction and the associated changes in participatory requirements, impact upon students' perceptions of social or functional value? Furthermore, does this in turn influence students' likelihood of satisfaction, recommendation and return?

The purpose of this paper is to address this important gap in the literature. Firstly, this paper will examine the relative importance of perceived value within the sector. This paper will then explore whether the use of an interactive class-based technology moderates students perceptions of perceived value in the establishment of student loyalty. The research questions addressed in this paper include; How important is student perceived value, specifically, social and functional value, in determining student recommendation and loyalty? Does the relative importance of these antecedents to loyalty differ when using an interactive class based technology to facilitate the learning process or not? In order to answer these interrelated questions a partial least squares modelling approach is employed to investigate the relationship between value, satisfaction and loyalty for students undertaking a technology facilitated versus interaction facilitated class.

The paper is organized as follows. The next section provides a brief discussion of marketing in the higher education sector. It will then review the literature on loyalty, satisfaction and perceived value as it applies to the higher education sector. Interactive technologies will be introduced as one mechanism by which to increase the co-production of the higher education experience. The use of such technologies is presented as an important determinant of students' value perceptions. The propositions supporting these research gaps will then be presented. The research model is presented in Figure 1. The paper concludes with a discussion of the theoretical and managerial findings from this study, after which a conclusion is offered. 


\section{Adopting a Customer Orientation in the Higher Education Sector}

Most institutions recognise that there is a need to market themselves in order to develop a clear positioning and positive reputation amongst competitors (Hemsely-Brown \& Oplatka, 2006). In addition, understanding students' needs and expectations enables institutions to provide students with a high quality educational experience. A marketing approach within the sector is appropriate given that higher education involves a service exchange. That is, because it is an intangible knowledge-oriented offering, education is considered as a performance whereby the value derived is more directly related to the experience itself, as opposed to any form of tangible good or physical evidence that arises from the service (Clewes, 2003). Importantly, education also involves the simultaneous production and consumption of the service. That is, "people", both students and staff, are inherently involved in the production of the educational experience (Binsardi \& Ekwulugo, 2003; Hemsley-Brown \& Oplatka, 2006) and the service is consumed at the same time that it is produced. For example, educators provide and respond to information which is cognitively, emotionally and behaviourally acted upon by the students' who receive and respond to it. The service exchange is therefore dyadic, and two-way. A marketing perspective therefore recognises that understanding client perceptions and their service evaluation processes are essential to ensuring retention and loyalty (Thomas \& Cunningham, 2009; Ledden, Kalafatis \& Samouel, 2007).

In addition, we also adopt the perspective that the student should be viewed as a customer of the higher education institution. This is because students are direct participants of knowledge co-construction (Yeo, 2009) and they are therefore highly active participants in service exchanges. The institutions role is not therefore to statically deliver product information to passive student recipients (McColl-Kennedy, Vargo, Dagger \& Sweeney, 2009). Learning is not considered a one-way process. Rather the role of the institution is to actively participate and dynamically interact with the student base. Students can therefore be regarded as 'partial employees' of tertiary institutions. The concept of customer participation in the service sector is not particularly new; what is new however is the recognition that the educational institution only provides partial input into the customer's experience (McColl-Kennedy et al., 2009). It is therefore essential to co-opt and empower students to take on a co-creation role in education (Vargo \& Lusch, 2004). On this latter point Carvalho and de Oliveira Mota (2010) note that the co-creation of the experience itself directly contributes to students perceptions of value. Viewing the student as a customer therefore involves engaging in interaction, feedback and an interpretative process which results in shared meaning. Involving students in the learning process through the use of classroom technologies may enhance this approach.

Anderson (2003) further points out that interaction with the service provider and other student customers facilitates learner control, enables program adaption and flexibility and aids the development of meaningful learning. Exchange between students, peers and their educators is also considered a key element of constructivist learning approaches and may provide the foundation for transformational learning (Anderson, 2003; Yeo, 2009). Despite this relatively little is known about the mechanisms for facilitating co-creation of the educational experience and the effects that co-creation has on student loyalty, student satisfaction, and student perceived value. The conceptual model is presented in Figure 1. The propositions associated with the model are presented next.

\section{Conceptual model and propositions}

\subsection{Student loyalty}

Loyalty is defined in the services marketing literature as a "deeply held commitment to rebuy or to repatronise a preferred product/service consistently in the future, thereby causing repetitive same-brand or same-brand set purchasing, despite situational influences and marketing efforts having the potential to cause switching behaviour" (Oliver 1999, p. 34). High levels of customer loyalty have been found to result in reduced marketing costs, increased market share, and enhanced consumer resistance to competitor strategies (Baldinger \& Rubinson 1996; Chaudhuri \& Holbrook 2001; Bowen \& Chen 2001; Rundle-Thiele 2005). In the higher education context, student loyalty has received increasing attention in the literature (e.g., Carvalho \& de Oliveira Mota 2010; Arnett, German \& Hunt 2003; Hennig-Thurau, Langer \& Hansen, 2001).

A range of antecedents have been found to predict loyalty within the higher education context. These include for example: institutional reputation, facilities, social interaction (Helgesen 2008; Helgesen \& Nesset 2007), service quality (Hill 1995), and image (Mguyen and LeBlanc 2001; Hemsley-Brown \& Oplatka 2004). Studies have also found that co-production of the educational experience (Kotze \& du Plessis 2003), satisfaction (Athiyaman 1997), trust (Carvalho \& de Oliveira Mota 2010) and commitment towards the institution (Tinto 1993) strongly determine student loyalty. 
Helgesen \& Nesset (2007) note that student loyalty is not simply restricted to students attitudes and intention to recommend the service during the period they are formally registered in for their qualification. Rather, loyalty can extend beyond the completion of a degree or course to include attitudes and behaviours following graduation from the institution. Student loyalty therefore may lead to a range of long term benefits for the institution including donations, co-operation and positive word-of-mouth communications (Marzo-Navarro et. al, 2005). High levels of student loyalty have also been found to lead to repeat purchase through continuing education (Mavondo et al. 2004).

Understanding the processes by which student loyalty develops, as well as the drivers of positive recommendation, and intention to return will provide management with the opportunity to manipulate the determinants of loyalty to strengthen the student-institution relationship. This paper will next review the role of two major antecedents to loyalty, namely student satisfaction and student perceived value. It will then explore the moderating effect of interactive classroom based technology on the value-satisfaction-loyalty chain.

\subsection{Student satisfaction}

Customer satisfaction is defined as the extent to which the service provided consistently meets customers' expectations (Delgado-Ballester \& Munuera-Aleman 2001) as well as the level of consumption related fulfilment received (Oliver 1997; Verhoef et al. 2002). Satisfaction is typically identified as the primary determinant of loyalty, and a major driver of relational outcomes within the customer-brand relationship. Importantly, customers who display high levels of customer satisfaction have been found to have a higher propensity for loyalty. They have also been found to display an increased propensity to repurchase and to recommend the product or service to others (Fornell, 1992).

In the higher education sector, student satisfaction has been defined as a short term attitude which arises from the students' evaluation of the educational experience, which is subjective in nature (Elliott \& Shin, 2002). Student satisfaction has been found to positively influence student loyalty through positive recommendation (e.g., Mavondo et al. 2004; Marzo-Navarro, Pedraja \& Rivera 2005; Hennig-Thurau et al. 2001), increased revenue and reduced costs for educational institutions (Shah 2009), and continued education (Al-Alak 2006; Helgesen \& Nesset 2007). Consequently satisfaction may be assumed to positively affect student loyalty. We propose that:

\section{P1: Student satisfaction is directly and positively related to student loyalty.}

Whilst satisfaction is an important determinant of customer loyalty, it is critical that research also examines the role of other non-satisfaction determinants of loyalty (Oliver, 1999). It is also critical that research explore the role of other non-traditional antecedents such as students' perceptions of value in the formation of customer loyalty.

\subsection{Student perceived value}

The concept of perceived value emerged in the services marketing literature in the 1990's where it was noted that the creation of customer value was at the core of a firms reason for existence, as well as their success in the market. Mathwick, Malhotra and Rigdon (2001) point out that as the customer shifts from a spectator-based role to an active participant in service creation, they are also shifting from passive recipient to an active co-producer of value.

A number of conceptualizations with regard to the nature of perceived value have been put forward in the literature including quality-price conceptualizations, utilitarian versus hedonic value, hierarchical values and consumption values. This study draws on this later conceptualization on the basis that this conceptualization has strong theoretical grounding across service contexts within the higher education sector including economics, sociology, psychology and consumer behavior (Ledden, Kalafatis \& Samouel, 2007; LeBlanc \& Nguyen, 1999) and its generalisability across 200 applications (Sweeney \& Soutar, 2001).

Perceived value is considered in this paper to be multidimensional and multifaceted in nature. It is defined as "the consumer's overall assessment of the utility of a product (or service) based on perceptions of what is received and what is given" (Zeithaml, 1988, p. 14). According to consumption-value theory, perceived value rests on three fundamental propositions: a) that consumer choice within a market is a function of five types of value, b) that these types of value contribute differentially to choice behavior and that c) the types of value are independent of one another (Sanchez-Fernandez \& Iniesta-Bonillo, 2007).

The forms of value can be categorized as functional, social, emotional epistemic and conditional. Functional value refers to whether the service can perform its utilitarian purposes. In the current educational context this refers to students expectations that obtaining an undergraduate degree will enable them to achieve their career goals (LeBlanc \& Nguyen, 1999). Vekiri and Chronaki (2008) note that students are more likely to pursue 
academic activities that are considered valuable and which are closely aligned with students' future career objectives. Functional value has been found to be the primary determinant of value perceptions in prior studies and more specifically in the higher education sector where the price/quality trade-off was found to predict student loyalty (LeBlanc \& Nguyen, 1999).

Social value refers to the benefits derived from interaction with the service provider and other groups of customers within the service context. In the higher education context this refers to the value that students perceive from interacting with peers both in-class and external to class (LeBlanc \& Nguyen, 1999). Research has found that the social aspect of the university experience is important in determining students' intentions to remain with the institution (Thomas, 2002). This is in part due to the fact that social networks not only facilitate learning and the sharing of ideas, social networks also act as a form of social capital and assist students in overcoming challenges throughout their educational experience. Collaborative teaching approaches which aim to co-create the educational experience both with and between students have been strongly linked to increases in perceived social value (Thomas, 2002). It is suggested therefore that "the institutional habitus should not restrict itself to influencing only the academic, but it should link together the academic and social spheres of higher education" (Thomas, 2002, p. 438).

Emotional value refers to the various positive and negative affective states that may arise from a consumption experience. In the current context this relates to students perceptions of enjoyment and gladness in undertaking their studies (LeBlanc \& Nguyen, 1999). Epistemic value refers to customers desire for knowledge whether this is based on novelty, or genuine intellectual curiosity. The latter applies particularly strongly within the higher education context (LeBlanc \& Nguyen, 1999). Lastly, conditional value refers to the situation in which the service is being consumed. In the higher education context this relates to the provision of specific teaching aids and materials and the impact that this has on students perceptions of value (Ledden, Kalafatis \& Samouel, 2007).

Understanding students' perceptions of value can assist in tailoring the educational offerings to the needs of the student base. It can also assist in optimizing the students learning experience (Ledden, Kalafatis \& Samouel, 2007). Based on the research evidence presented above, we propose that:

\section{P2: Perceived value is directly and positively related to student satisfaction}

\section{P3: Perceived value is directly and positively related to student loyalty}

\subsection{The moderating role of interactive technology}

The use of interactive technologies in higher education has gained popularity in the last decade in response to an increasingly digital generation, and also increasing enrolments and class sizes (Kennedy \& Cutts, 2005; Boyle \& Nicol, 2003). These technologies appear in the literature under different names such as electronic voting systems (EVS), audience response systems, personal response systems, and classroom communication systems (Fies \& Marshall, 2006). They vary in form, however they generally involve the use of a series of student-held handsets which remotely connect to a hardware base, allowing educators to display multiple choice questions, collect student answers, and provide a class wide display of student answers to each question. The presentation of responses in aggregated histogram format then provides a springboard for class wise discussion. Such systems require little capital investment, and as a result provide immense flexibility with regard to implementation.

These systems have been introduced in order to facilitate a shift from a passive, educator focused teaching style, to a more interactive, organic, and student centred style (Dufresene, Gerace \& Leonard, 1996). This approach recognises that the modern student has been brought up with technology and are adept at utilising technology to access and assess information (Kennedy, Judd, Chruchward, Gray \& Krause, 2008). It also recognises that students wish to be actively engaged in learning activities and that student learn more effectively when they are constructing their own knowledge with other parties (Dufresne, Gerace \& Leonard, 1996).

Interactive classroom technologies have been linked to a variety of positive outcomes such as; increased interaction and engagement, increased understanding of student comprehension and application of theoretical concepts, responsive feedback (Fies \& Marshall, 2006); increased participation due to anonymity (Kennedy \& Cutts, 2005), increased class attendance (Elliott, 2003), enhanced conceptual reasoning (Nicol \& Boyle, 2003) and cognitive integration between concepts (Kennedy \& Cutts, 2005). From these studies one would assume that the use of in-class interactive technology not only facilitates and enhances student learning, and the co-production of learning, but that it is also perceived as a beneficial augmentation to the traditional lecture format, and adds value to the students learning experience.

Despite the reported benefits of such technologies, research has not yet investigated the use of classroom technologies from a marketing and managerial perspective. That is, does the use of interactive technologies 
increase students' perceptions of satisfaction with the higher education service, and does it also increase their perceptions of perceived value with the service? Expressed differently, is it the medium itself that is the most important factor in educational programs, or is it the way in which learning activities are exploited and constructively aligned with students' needs? To address this gap in the literature we conduct an experimental investigation of the use of interactive technologies in large class delivery by comparing the results of a technology-enabled delivery to a more traditional non-technology enabled, interactive lecture.

\section{Method}

Participants in this investigation were students enrolled in a compulsory first year undergraduate marketing unit at an Australian University. A subset of students from two lecture streams in this unit participated in the study (n $=184$ ). One lecture stream was assigned to the technology condition, and the other stream was assigned to the traditional lecture condition. All aspects of the lecture theatre teaching strategy were held constant except for the response method. Table 1 summarizes the two teaching methods.

A series of thirty multiple choice questions were developed prior to the class. The questions were a combination of conceptual and applied problems. Prior to indicating their response, students were requested to discuss the concept question with their neighbour in the theatre. The time allowed per question varied based on the difficulty of the question. Students were then asked to provide their individual responses to the question posed in two possible ways.

Responses in the technology condition were indicated using a wireless electronic response system via students' mobile phones in one class. Students were given two weeks advanced notice to register their mobile phone with a Clicker technology system so that they could participate in the interactive lecture. Registrations indicated that $81 \%$ of the interactive technology class registered with the Clicker system. Students indicated their answer by dialling a mobile number which represented one of the multiple choice solutions. An engaged ringtone would then sound indicating that their response to the question had been received and processed. This service was provided free of charge. In class the questions were displayed via projector, and solutions were projected in aggregated histogram form with the correct response highlighted. No assessment value was attached to the learning activity. Following presentation of the histogram and correct solution, the educator would then lead further discussion of the question and its solutions. In the traditional condition class responses were indicated by a show of hands for each multiple choice solution. The educator would announce the correct solution. No assessment value was attached to the learning activity. Following presentation of the correct solutions, the educator would then lead further discussion of the question and its solutions.

A total of 184 students were surveyed at the conclusion of the class to ascertain their perceptions of the experience in terms of perceived value, satisfaction and secondary loyalty behaviours such as their intention to recommend the class to others. This represented a response rate of $76 \%$. The survey was paper based. Each item in the survey was linked back to either the students' perceptions of the use of the Clicker technology in class, or students' perceptions of the use of socially interactive teaching styles. If the use of technology is an enhancing and value adding factor in the provision of higher education services then we would expect to see a significant difference in students perceptions of perceived value, satisfaction and loyalty between the Clicker and traditional teaching groups.

\subsection{Measures}

In order to test the hypotheses, the variables for each set of measures, standardized loadings, alpha's, means and standard deviations were measured. All variables were scored using a Likert scale from 1 (Strongly Agree) to 7 (Strongly Disagree). Measures of perceived value were adapted from (LeBlanc \& Nguyen, 1999) and were designed to explore functional, social, emotional, and epistemic value. Conditional value was not considered relevant in the present study context and was excluded from the perceived value scale items. An exploratory factor analysis was initially conducted on all perceived value items. Contrary to LeBlanc and Nguyen's (1999) original study with business college students where all five forms of value exist, this study found that following a varimax rotation, only two main value factors existed. This may in part be due to the fact that a sample of first year students was used. Future career objectives, goals and outcomes, may therefore be perceived by this cohort as being somewhat remote from their current circumstances. These two factors were labelled Functional and Social Value and explained $94.8 \%$ of the variance in student loyalty. Measures of satisfaction were adapted from the existing scales of Hennig-Thurau, Gwinner and Gremler (2002). An exploratory factor analysis suggested that the measure was one-dimensional. Finally the scale items for student loyalty were adapted based on Hennig-Thurau, Lager and Hansen (2001). These were also found in the exploratory factor analysis to be unidimesional in nature. Appendix A shows the measurement properties of the major scales of the study. The 
average variance extracted (AVE) for all measures were above the criteria of .50 (see Fornell \& Larcker 1981). The composite reliability measures, similar to the construct reliability measures of Bollen (1989), showed that each latent construct was well represented by the observed measures and ranged from .82 to .99 . One open ended question was included which asked students to comment on the nature of the classroom delivery and their level of engagement during the delivery.

\subsection{Results}

In order to evaluate the hypothesis a two stage analysis was used. First any differences between the control and experimental groups were examined by use of a t-test. The path models for both the groups were then investigated by use of a partial least squares analysis. The use of an interactive technology classroom delivery did not lead to any significant differences in student loyalty or student satisfaction with the unit of study or the university. There were marginal differences $(p<.10)$ in social and functional value. Figure 1 and 2 summarize the partial least square results which were used to develop the measurement model and evaluate the hypotheses. PLS was preferred given the large number of measures and the small sample size (Chin et al. 1999). The significance of the path betas were calculated using bootstrapping, (65 samples) and the resultant t-tests were used to evaluate the hypotheses. As shown in Figure 1, in the traditional classroom interaction only group, functional value predicted the social value $(\beta=.71, \mathrm{t}=2.41, \mathrm{p}<.05)$, but did not predict student satisfaction or loyalty. Social value strongly predicted student loyalty $(\beta=.71, \mathrm{t}=2.02, \mathrm{p}<.05)$. This relationship explained the variation of loyalty scores for this group quite well $\left(\mathrm{r}^{2}=.49\right)$. In the interactive technology condition, the relationship between social value and loyalty is not significant and the relationship between functional value and satisfaction is negative $(\beta=-.35, \mathrm{t}=1.76, \mathrm{p}<.05)$.

\section{[Insert Figures $1 \& 2$ Here]}

Analysis of one open ended qualitative survey item provided further support for the unexpected statistical results. One question was included in the survey instrument which asked respondents to comment on nature of the two classroom deliveries and their engagement during these sessions. Student comments in the interactive technology condition were mixed. Students in this condition commented that they felt somewhat disengaged and isolated during interactive classes. Positive experiences of the interactive class referred to obtaining topic tips, and improved self-testing/learning.

\section{"I could check my understanding of the topics by testing myself." \\ "It was different using technology in class, but i didn't really get a feel for how much other students knew." \\ "Looking at class results on a histogram was interesting, but i felt uninvolved in the class, i don't know, it didn't seem engaging."}

Conversely, students in the traditional, interactive class format condition revealed that they perceived benefit in the interaction between their peers and their educator. Students' commented that the discussions between members of the class were beneficial to their own understanding of the topic content, and allowed them to develop their ideas and check these against other students in the class.

"When the lecturer and students involve in class discussions and debate, everyone is able to raise their thoughts /issue and get fair response for it."

"...the lecturer made it very interesting and interactive."

"I thought it was a good class, it was fun."

The nature of these open ended responses confirmed the view that students perceived a relationship between the value that they received from increased personal interaction in the traditional format (social value), and their perceptions of loyalty to the university. Conversely in the technology condition, the student responses appeared to suggest that the use of interactive technology interfered with the educator-student and student-student interaction. In this study, the interaction between these parties was an important mechanism for the establishment of perceived value.

\section{Discussion}

In the introduction of this study, it was suggested that viewing the student as a customer of the higher education service would enable management to better understand their customer base and would subsequently allow management to tailor the service provision to more effectively meet students' needs. In turn, it was noted that adopting a customer oriented marketing perspective, would also provide higher education management with a framework with which to assess which aspects of the learning experience enhance co-production of education, 
and encourage participation in service provision. It was also argued that this will assist in the development of service delivery strategies which enhance student satisfaction, add value to the educational experience and result in positive loyalty outcomes for the higher education provider.

A number of authors have argued that the use of technology-enabled classes have advantages over basic non-technology enabled approaches and that classroom communication technologies add value to the student experience (Dufresene, Gerace \& Leonard, 1996; Kennedy \& Cutts, 2005; Nicol \& Boyle, 2003). In particular technology-enabled classes are suggested to: enhance the quality of feedback, provide instantaneous feedback, allow students to benchmark their performance relative to peers, enable co-construction of knowledge structures, and promote interaction due to the anonymity that technology-enabled classes provide. Given the highly interactive nature of technology-enabled classes, it was expected that the use of an interactive technology would be positively associated with students' perceptions of satisfaction, value and loyalty.

A compelling finding of this study was that this was not the case and in fact the use of technology resulted in a negative relationship between student perceived functional value and loyalty. Technology was not found to be positively related to the student experience. This is interesting since one would assume that the mere novelty of introducing a new technology into the classroom would stimulate curiosity and interest. Several explanations can be put forward in this regard.

Firstly, social value was not positively related to satisfaction and loyalty in the technology condition. This is a remarkable finding since a social aspect was present in the technology enabled condition in the form of class-wide, peer based discussions prior to and after the presentation of each sample question. It seems reasonable to suggest when students are responding to questions using Clicker technology they are engaging in a highly individualistic process of thinking about the material presented and they are then responding to it on an individual basis. Whilst it is true that many students engaged in the interactive, peer discussion aspects of the class prior to and following their electronic response, students who did not engage actively in class-wide discussion, or who were not deeply processing information to reconstruct their knowledge structures, may find the use of technology a disadvantage. It may therefore be the case that individually responding to the question via personal wireless devices again isolates the student from perceiving a social experience, and that this individual response process over powers any social aspect that the experience provided.

In line with the findings of Kennedy and Cutts (2005), the use of Clickers may only be advantageous for students who: have a baseline knowledge from which to develop, who are reasonably confident in their academic skills, who are actively engaged with the content of the unit and motivated to learn and discuss their perspectives, and who have a high level of interest in vocally participating in class wide discussions. Students who do not fit this profile, may view the use of Clickers as an isolating experience which in fact disengages them. In the current context, the use of technology by students appeared to break classroom social patterns, instead of fostering social exchange. Therefore, it may be that the benefits of using interactive technologies are only apparent when the abovementioned conditions are met. If this is the case, then management should assess the nature of their student cohort, their comfort with technologies, and their base understanding of unit material prior to implementing technology facilitated classes within their educational program.

The second compelling and contrasting finding was that perceived social value strongly and positively determined students' perceptions of loyalty to the institution in the non-technology condition. This suggests that it is the pedagogy, and not the technology that matters in higher education provision. This finding addresses the concerns of Freeman and Blayney (2005, p. 32) who note that "if interactivity in pedagogical design is the key to an improved learning experience, an electronic response system needs to be compared with a traditional approach where interactivity is present". That is, these findings suggest that a sense of classroom community and indeed value in the educational experience can be developed irrespective of facilitating technologies (Roschelle, 2003). Additionally, in this case, removing the use of individualistic technology actually enhanced the quality of social interaction, discussion and flow during the class. This in turn may have inadvertently emphasized to students that the session was premised on a large-group discussion forum and a 'meeting of the minds'. This unrestricted form of social interaction may subsequently have led to an increase in perceived social value.

A second explanation for this finding can be extrapolated from the work of Dufresene, Gerace \& Leonard (1996). They suggest that co-construction of knowledge is essential to enhancing perceptions of value within the educational experience. They therefore argue that all education is by its very nature socially mediated. The finding that students' perceived greater social value from a non-technology mediated class experience does not sit easily with prior research which argues that anonymity is a desirable and necessary determinant of student learning. This study in fact argues that the opposite may be true. That is, students are more engaged with the 
educational experience when open discussion is fostered, when students are allowed to question one another's reasoning, and when they are allowed to challenge their understandings with the educator. It appears that perceived value is enhanced under these conditions and that the student is in fact more motivated to interact when their contributions can be identified. This explanation fits well with constructivist theories of learning and highlights the point that exposure to another peer's way of thinking and perspective, is essential to the creation of value for the student. Based on this finding, higher education management should aim to empower students' individual and collective voices during the educational experience. They should also encourage students to move beyond surface learning to deep learning facilitated by active and rigorous peer and educator driven discussion. In addition management may emphasise imagery associated with socialization opportunities within the institution generally for example, societies, clubs, meetings places and events, as well as within the classroom situation through group work, peer interaction, and the promotion of interactive class learning experiences.

This study found that functional value did determine students' perceptions satisfaction or loyalty in the technology condition, but in a negative manner. That is, beliefs about how their education influences their career direction, employment opportunities, salary levels and potential for promotion negatively predicted their level of satisfaction with the institution and their intentions to recommend the institution. Students' beliefs regarding the quality of the education and the economic value that it offers also failed to positively determine satisfaction and loyalty. LeBlanc and Nguyen (1999) in contrast found that functional value in terms of students price and quality perceptions, was the most important factor determining students overall perceptions of value of their educational program. At first glance the contradictory findings of this study seem unusual; however these contradictory findings may be due to the nature of the sample. Students responding to these items were first year undergraduates in a business program. For these students the prospect of employment, and their future career potential may, at this early stage of their education be viewed as remote issues. LeBlanc and Nguyen's study in contrast explored the perceptions of students across all year groups perhaps explaining the strong role of functional value in their regression analysis. Students', who are more advanced in their studies, are more likely to start to form linkages between their current student status and their not too distant career prospects. This is not to say that management should ignore marketing appeals and communications that focus on functional, end-benefit outcomes for students. This is certainly an important part of process of attracting target markets to higher education institutions, particularly those that base their offerings on industry opportunity. Rather management should realize that the determinants of loyalty for students early in their programs may be driven more so by social factors. It may therefore be the case that whilst social factors drive value perceptions early in the educational process, functional career based assessments may determine value for students who are further on in the process. Management may therefore tailor message appeals to meet these varying cohort needs.

Finally, perceived value (functional and social) was not found to influence student satisfaction, and satisfaction was not found to determine loyalty in both the technology and no-technology conditions. This is contrary to previous research which has found that value is associated with student satisfaction and that satisfaction strongly drives loyalty in higher education (Marzo-Navarro, Pedraja \& Rivera 2005; Athiyaman, 1997; Al-Alak 2007). This suggests that satisfaction may operate only as a minimum requirement for loyalty in the sector. In highly involving service contexts where customers have high anticipatory expectations shaped by word of mouth recommendation, the customer may reasonably expect to be satisfied. A confirmation bias may then operate to assimilate satisfaction levels to expectation levels (Syzmanski \& Henard 2001). Whilst satisfaction measurement is an important first step in developing an understanding of the determinants of student loyalty, in this study satisfaction alone was not an important factor in determining students' loyalty perceptions.

\section{Conclusion}

During the past decade there has been an increased focus on managing the student experience and increasing student participation and co-creation in higher education. Recently research has attempted to address the role of technology in facilitating this process and the extent to which technology positively impacts upon the student experience. From a marketing perspective, it is necessary to understand whether technology facilitated learning increases students' perceptions of value, satisfaction and therefore loyalty to the institution. Understanding the drivers of student loyalty will enable management to manipulate the delivery of the educational experience in order to more effectively meet the needs of its student customers. This study has contributed to that literature by comparatively examining an enhanced classroom delivery using Clicker interactive technology, and more traditional class-based interaction in order to ascertain the effect of technology on students' service evaluations.

The finding that technology did not enhance student perceptions of value, satisfaction and loyalty in the study context is novel. The findings draw attention to the types of interactivity that may exist in the higher education service, as well as the differential effect that interaction may have on students' evaluations of the service 
experience. In particular the findings suggests that an uncoupling between technology and the more traditional social interaction based approaches to service provision in the sector is required if we are to understand how these two types of interaction enhance, or detract from the student experience. This study also suggests that a clearer identification of the separate roles of technology facilitated learning and learning based on interpersonal communication is required. Technology may for example perform a small and well-defined role in the provision of higher education services, but the weight of the student experience appears to be created through social practices. Clearly understanding the role of these two forms of interaction will allow higher education management to better understand technology's affordances and limitations, and in turn will assist in the development of an educational service which delivers high levels of value and satisfaction to the student.

\section{References}

Al-Alak, B. (2006). The Impact of Marketing Actions on Relationship Quality in the Higher Education Sector in Jordon. Journal of Marketing for Higher Education, 16(2), 1-23. http://dx.doi.org/10.1300/J050v16n02_01

Anderson, T. (2003). Getting the mix right again: An update and theoretical rationale for interaction. The International Review of Research in Open and Distance Learning, 4(2), 1492-3831.

Arnett, D., German, S. and Hunt. S. (2003). The Identity Salience Model of Relationship Marketing Success: The Case of Nonprofit Marketing. Journal of Marketing, 67(4), 89-105. http://dx.doi.org/10.1509/jmkg.67.2.89.18614

Athiyaman, A. (1997). Linking student satisfaction and service quality perceptions: The case of university education. European Journal of Marketing, 31(7), 528-540. http://dx.doi.org/10.1108/03090569710176655

Baldinger, A. and Rubinson, J. (1996). Brand Loyalty: The Link Between Attitude and Behaviour. Journal of Advertising Research, 36(6), 22-34.

Binsardi, A. and Ekwulugo, F. (2003). International Marketing of British Education and Research on Students Perception and the UK Market Penetration. Marketing Intelligence \& Planning, 25(5), 318-327. http://dx.doi.org/10.1108/02634500310490265

Bollen, K. A. (1989). Structural Equations with Latent Variables. Wiley Series in Probability and Mathematical Statistics. New York: Wiley.

Bowen, J. and S. Chen. (2001). The Relationship Between Customer Loyalty and Customer Satisfaction. International Journal of Contemporary Hospitality Management, 13(5), 213-217. http://dx.doi.org/10.1108/09596110110395893

Boyle, J. and Nicol, D. (2003). Using classroom communication systems to support interaction and discussion in large class settings. Association of Learning Technology Journal, 11(3), 43-57. http://dx.doi.org/10.1080/0968776030110305

Carvalho, S. and de Oliveira Mota, M. (2010). The role of trust in creating value and student loyalty in relational exchanges between higher education institutions and their students. Journal of Marketing for Higher Education, 20(1), 145-165. http://dx.doi.org/10.1080/08841241003788201

Chaudhuri, A. and Holbrook, M. (2001). The Chain of Effects from Brand Trust and Brand Affect to Brand Performance: The Role of Brand Loyalty. Journal of Marketing, 65, 81-93. http://dx.doi.org/10.1509/jmkg.65.2.81.18255

Chin, W., and Newsted, P. (1999). Structural Equation Modelling analysis with Small Samples Using Partial Least Squares. In Rick Hoyle (Ed.), Statistical Strategies for Small Sample Research. Sage Publications, 307-341.

Clewes, D. (2003). A student-centred conceptual model of service quality in higher education. Quality in Higher Education, 9(1), 69-85. http://dx.doi.org/10.1080/13538320308163

Delgado-Ballester, E. and Munuera-Aleman, J. (2001). Brand Trust in the Context of Consumer Loyalty. European Journal of Marketing, 35(11/12), 1238-1258. http://dx.doi.org/10.1108/EUM0000000006475

Draper, S. and Brown, M. (2004). Increasing interactivity in lectures using an electronic voting system. Journal of Computer Assisted Learning, 20(2), 81-94. http://dx.doi.org/10.1111/j.1365-2729.2004.00074.x

Dufresne, R. Gerace, W. Leonard, W. Mestre, J. and Wenk, L. (1996). Classtalk: A classroom communication system for active learning. Journal of Computing in Higher Education, 7, 3-47. http://dx.doi.org/10.1007/BF02948592 
Elliott, C. (2003). Using a personal response system in economics teaching. International Review of Economics Education, 1(1), 80-86.

Elliott, K., and Shin, D. (2002). Student satisfaction: An alternative approach to assessing this important concept. Journal of Higher Education Policy and Management, 24(2), 197-209. http://dx.doi.org/10.1080/1360080022000013518

Fies, C. and Marshall, J. (2006). Classroom response systems: A review of the literature. Journal of Science Education and Technology, 15(1), 101-109. http://dx.doi.org/10.1007/s10956-006-0360-1

Fornell, C. and Larcker, D. (1981). Evaluating Structural Equation Models with Unobservable Variables and Measurement Error. Journal of Marketing Research, 8, 39-50. http://dx.doi.org/10.2307/3151312

Freeman, M. and Blayney, P. (2005). Promoting interactive in-class learning environments: A comparison of an electronic response system with a traditional alternative. In S. L. Cheung (Ed), Innovation for Student Engagement in Economics: Proceedings of the Eleventh Australasian Teaching Economics Conference, 23-34.

Gerbing, D. and Anderson, J. (1988). An Updated Paradigm for Scale Development Incorporating Unidimensionality and Its Assessment. Journal of Marketing Research, 25(2), 186-192. http://dx.doi.org/10.2307/3172650

Helgesen, O. (2008). Marketing for Higher Education: A Relationship Marketing Approach. Journal of Marketing for Higher Education, 8(1), 50-78. http://dx.doi.org/10.1080/08841240802100188

Helgesen, O. and E. Nesset, E. (2007). Images, Satisfaction and Antecedents: Drivers of Student Loyalty? A Case Study of a Norwegian University College. Corporate Reputation Review, 10(1), 38-59. http://dx.doi.org/10.1057/palgrave.crr.1550037

Hemsley-Brown, J. and Oplatka, I. (2006). Universities in a Competitive Global Marketplace: A Systematic Review of the Literature on Higher Education Marketing. International Journal of Public Sector Management, 19(4), 316-338. http://dx.doi.org/10.1108/09513550610669176

Hennig-Thurau, T., Langer M., and Hansen, U. (2001). Modelling and managing student loyalty: An approach based on the concept of relationship quality. Journal of Service Research, 3(1), 331-344. http://dx.doi.org/10.1177/109467050134006

Hennig-Thurau, T., K. Gwinner and D. Gremler. (2002). Understanding Relationship Marketing Outcomes: An Integration of Relational Benefits and Relationship Quality. Journal of Service Research, 4(3), 230-247. http://dx.doi.org/10.1177/1094670502004003006

Hill, F. (1995). Managing service quality in higher education: The role of the student as -primary consumer. Quality Assurance in Education, 3(3), 1-21.

Kennedy, G. and Cutts, Q. (2005). The association between students' use of an electronic voting system and their learning outcomes. Journal of Computer Assisted Learning, 21, 260-268. http://dx.doi.org/10.1111/j.1365-2729.2005.00133.x

Kennedy, G. Judd, T. Churchward, A. Gray, K. and Krause, K. (2008). First year students' experiences with technology: Are they really digital natives? Australasian Journal of Educational Technology, 24(1), 108-122.

Kotze, T. and Plessis, P. (2003). Students as co-producers of education: A proposed model of student socialization and participation at tertiary institutions. Quality Assurance in Education, 11(4), 186-201. http://dx.doi.org/10.1108/09684880310501377

Leblanc, G. and Nguyen, N. (1999). Listening to the customer's voice: Examining perceived service value among business college students. The International Journal of Educational Management, 13(4), 187-198. http://dx.doi.org/10.1108/09513549910278106

Ledden, L. Kalafatis, S. and Samouel, P. (2007). The relationship between personal values and perceived value of education. Journal of Business Research, 60, 965-974. http://dx.doi.org/10.1016/j.jbusres.2007.01.021

Mansfield, P. and Warwick, J. (2006). Gender Differences in Students' and Parents' Evaluative Criteria When Selecting a College. Journal of Marketing for Higher Education, 15(2), 47-80. http://dx.doi.org/10.1300/J050v15n02_03

Marzo-Navarro, M., Pedraja., and Rivera. P. (2005). Measuring customer satisfaction in summer courses. Quality Assurance in Education, 13(1), 53-65. http://dx.doi.org/10.1108/09684880510578650 
Mathwick, C. Malhotra, N. and Rigdon, E. (2001). Experiential value: Conceptualization, measurement, and application in the catalog and internet shopping environment. Journal of Retailing, 77, 39-56. http://dx.doi.org/10.1016/S0022-4359(00)00045-2

Mavondo, F. Y. Tsarenko and M. Gabbott. (2004). International and Local Student Satisfaction: Resources and Capabilities. Journal of Marketing for Higher Education, 14(1), 41-60. http://dx.doi.org/10.1300/J050v14n01_03

Mills, P. and Morris, J. (1986). Clients as partial employees of service organizations: Role development and client participation. Academy of Management Review, 11(4), 726-735.

McColl-Kennedy, J. Vargo, S. Dagger, T. and Sweeney, J. (2009). Customers as resources integrators: Styles of customer co-creation. Proceedings of the Naples Forum on Services: Service Dominant Logic, Service Science and Network Theory conference, Capri: Italy.

Nicol, D. (2006). Increasing success in first year courses: Assessment re-design, self-regulation and learning technologies. Proceedings of the 23rd Annual ASCILITE conference, Sydney: Australia.

Oliver, R. (1997). Satisfaction: A Behavioral Perspective on the Consumer. New York: McGraw-Hill.

Oliver, R. (1999). Whence Consumer Loyalty? Journal of Marketing, 63, 33-44. http://dx.doi.org/10.2307/1252099

Parasuraman, A. and Grewal. (2000). The impact of technology on the quality-value chain: A research agenda. Journal of the Academy of Marketing Science, 28(1), 168-175. http://dx.doi.org/10.1177/0092070300281015

Roschelle, J. (2003). Unlocking the learning value of wireless mobile devices. Journal of Computer Assisted Learning, 19(3), 260-272. http://dx.doi.org/10.1046/j.0266-4909.2003.00028.x

Rundle-Thiele, S. (2005). Exploring Loyal Qualities: Assessing Survey-based Loyalty Measures. Journal of Services Marketing, 19(7), 492-500. http://dx.doi.org/10.1108/08876040510625990

Sanchez-Fernandez, R. and Iniesta-Bonillo, M. (2007). The concept of perceived value: A systematic review of the literature. Marketing Theory, 7(4), 427-448. http://dx.doi.org/10.1177/1470593107083165

Shah, A. (2009). The Impact of Quality on Satisfaction, Revenue, and Cost as Perceived by Providers in Higher Education. Journal of Marketing for Higher Education, 19(2), $125-141$. http://dx.doi.org/10.1080/08841240903451324

Sweeney, J. and Soutar, G. (2001). Consumer perceived value: The development of a multiple item scale. Journal of Retailing, 77, 203-220. http://dx.doi.org/10.1016/S0022-4359(01)00041-0

Szymanski, D. and Henard, D. (2001). Customer Satisfaction: A Meta-Analysis of the Empirical Evidence. Journal of the Academy of Marketing Science, 29(1), 16-35.

Thomas, J. and Cunningham, B. (2009). Clients' Satisfaction with Monopolistic Services and Commitment to the Organization: A University Context. Journal of Marketing for Higher Education, 19(2), 179-190. http://dx.doi.org/10.1080/08841240903463410

Thomas, L. (2002). Student retention in higher education: The role of institutional habitus. Journal of Educational Policy, 17(4), 423-442. http://dx.doi.org/10.1080/02680930210140257

Tinto, V. (1993). Leaving college: Rethinking the causes and cures of student attrition (2 ${ }^{\text {nd }}$ ed). Chicago IL: University of Chicago Press.

Vargo, S. and Lusch, R. (2004). Evolving to a New Dominant Logic for Marketing. Journal of Marketing, 68, 1-17. http://dx.doi.org/10.1509/jmkg.68.1.1.24036

Vekiri, I. and Charonaki, A. (2008). Gender issues in technology use: Perceived social support, computer self-efficacy and value beliefs, and computer use beyond school. Computers \& Education, 51, 1392-1404. http://dx.doi.org/10.1016/j.compedu.2008.01.003

Verhoef, P., P. Franses, J. and Hoekstra. (2002). The Effect of Relational Constructs on Customer Referrals and Number of Services Purchased from a Multiservice Provider: Does Age of Relationship Matter? Journal of the Academy of Marketing Science, 30(3), 202-216.

Yang, S., Alessandri, S., and Kinsey, D. (2008). An Integrative Analysis of Reputation and Relational Quality: A Study of University-Student Relationships. Journal of Marketing for Higher Education, 18(2), $145-170$. http://dx.doi.org/10.1080/08841240802487353 
Yeo, R. (2009). Service Quality Ideals in a Competitive Tertiary Environment. International Journal of Educational Research, 48(1), 62-76. http://dx.doi.org/10.1016/j.ijer.2009.03.004

\section{APPENDIX A}

\section{Scales Used to Represent Constructs}

Satisfaction (Coefficient alpha 0.82; Standardized loadings 0.50-0.93)

My choice to use this university was a wise one.

I am always delighted with this universities service.

Overall I am satisfied with this university.

I think I did the right thing when I decided to use this university.

Scale: Strongly disagree (1) to Strongly agree (7)

Functional Value (Coefficient alpha 0.99; Standardized loadings 0.90-0.99)

A degree will allow me to earn a good salary

A degree will allow me to achieve my career goals

The knowledge I have acquired I have acquired at my university will allow me to get promotions.

I believe employers are interested in i hiring students from my university

A degree from my university is a good investment

Considering the price I pay for tuition, I believe that my university offers sufficient services

I believe that my university offers quality services

Course content influences the value of my education

The quality of my education received from my lecturers influences my degree.

Scale: Strongly disagree (1) to Strongly agree (7)

Social Value (Coefficient alpha 0.99; Standardized loadings 0.99)

I learn new things from my classes

I like taking classes in business

I am glad that I choose units in business

The value of my education depends on my personal effort

I am happy when friends are in my classes

I find my units more interesting when friends are in my classes

Working in groups has a positive effect on the value of my education

Social activities at my university make my studies more interesting

Scale: Strongly disagree (1) to Strongly agree (7)

Loyalty (Coefficient alpha 0.99; Standardized loadings 0.99)

I'd recommend my unit to someone else

I'd recommend my university to someone else.

I'm very interested in keeping in touch with my Faculty.

If I was faced with the same choice again I would still choose the same unit.

If I was faced with the same choice again I would still choose the same University

Scale: Strong disagree (1) to Strongly agree (7) 
Table 1. Teaching approach

\begin{tabular}{|c|c|c|c|c|c|}
\hline $\begin{array}{c}\text { Teaching } \\
\text { Approach }\end{array}$ & $\begin{array}{c}\text { Powerpoint } \\
\text { Presentation }\end{array}$ & Questions & $\begin{array}{c}\text { Peer } \\
\text { Discussion }\end{array}$ & $\begin{array}{c}\text { Response } \\
\text { Method }\end{array}$ & $\begin{array}{c}\text { Post-response } \\
\text { Method }\end{array}$ \\
\hline Click-On & Yes & $\begin{array}{c}\text { Multiple } \\
\text { choice }\end{array}$ & Yes & Electronic & Yes \\
\hline $\begin{array}{c}\text { Non } \\
\text { Click-On }\end{array}$ & Yes & $\begin{array}{c}\text { Multiple } \\
\text { choice }\end{array}$ & Yes & $\begin{array}{c}\text { Show of } \\
\text { hands }\end{array}$ & Ys \\
\hline
\end{tabular}

Table 2. Means and Standard Deviations Across Experimental Groups

\begin{tabular}{cccc}
\hline & Interactive lecture & Mean & Std. Deviation \\
\hline Social Value & Click On lecture & $40.61^{*}$ & 6.27 \\
& No Click On lecture & 38.78 & 8.00 \\
Functional value & Click On lecture & $50.74^{*}$ & 9.74 \\
& No Click On lecture & 47.93 & 10.31 \\
Satisfaction & Click On lecture & 18.21 & 4.35 \\
& No Click On lecture & 17.36 & 4.92 \\
Loyalty & Click On lecture & 24.17 & 5.04 \\
& No Click On lecture & 23.30 & 6.25 \\
Note ${ }^{*}=\mathrm{p}<.10$ & & & \\
\hline
\end{tabular}




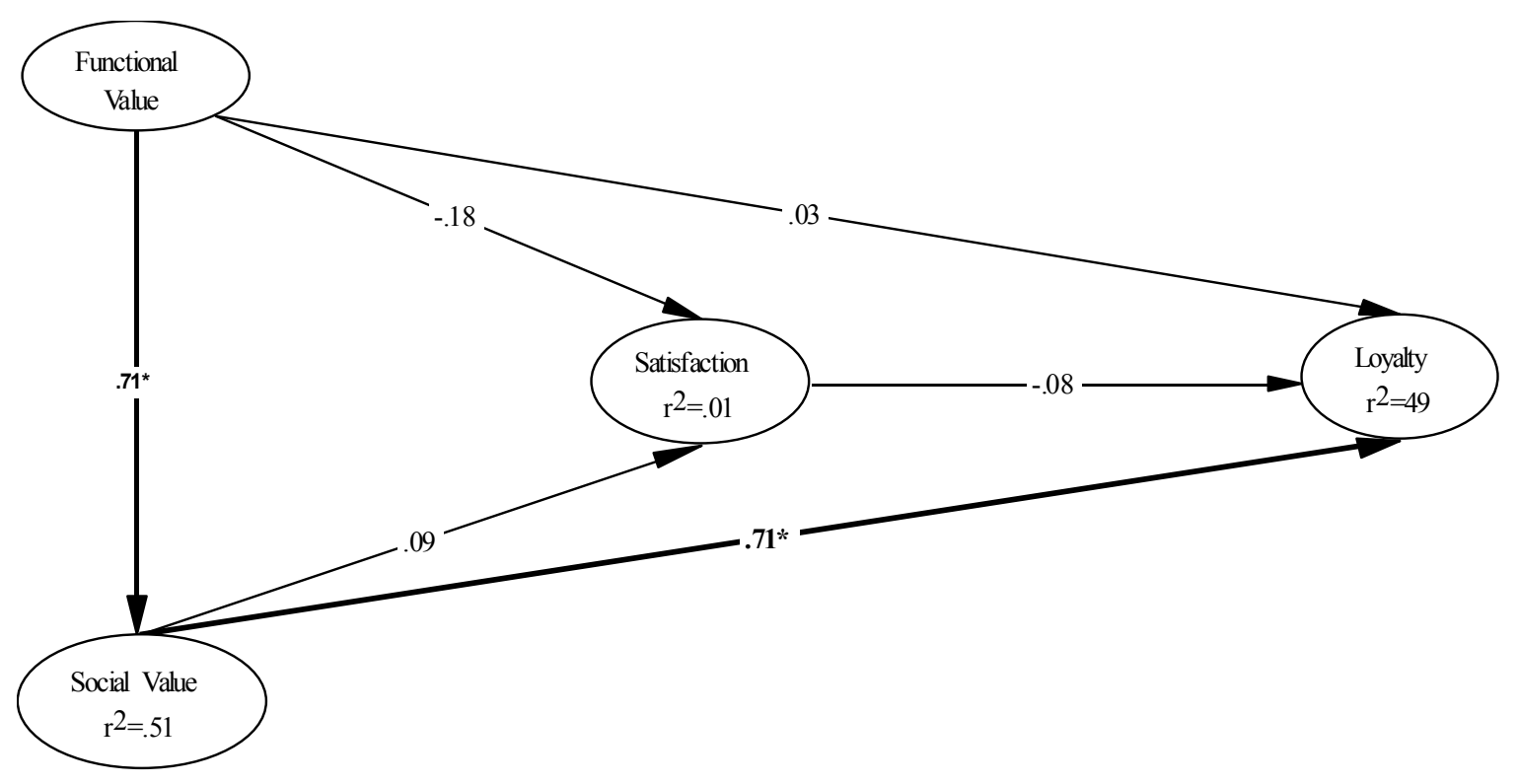

Figure 1. PLS Results Interaction Only Classroom ( $\mathrm{n}=91)$

Note: $*=\mathrm{p}<.05$

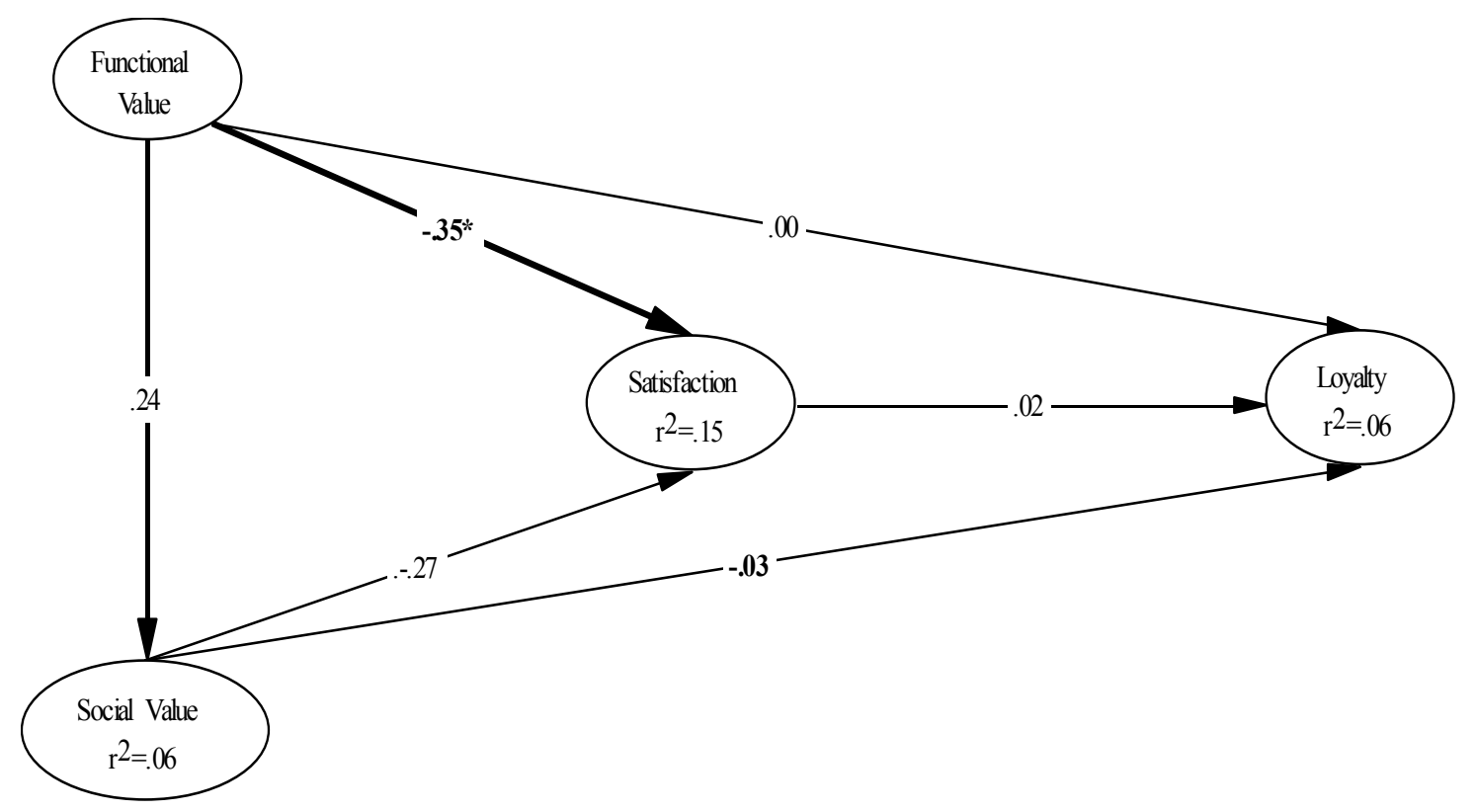

Figure 2. PLS Results Interactive Technology Classroom ( $\mathrm{n}=93$ )

Note: $*=\mathrm{p}<.05$ 